\title{
A Meal Replacement Program for the Treatment of Obesity: A Cost-Effectiveness Analysis from the Swiss Payer's Perspective
}

\author{
Mark Nuijten (D) \\ Livia Dainelli ${ }^{2}$ \\ Bahareh Rasouli $\mathbb{1 D}^{3}$ \\ Krysmaru Araujo Torres (iD 4 \\ Moreno Perugini ${ }^{5}$ \\ Agnieszka Marczewska ${ }^{2}$
}

'Health Economics and Valuation, A2M, Amsterdam, the Netherlands; ${ }^{2} \mathrm{Global}$ Market Access \& Pricing, Nestlé Health Science, Vevey, Switzerland; ${ }^{3}$ Institute of Environmental Medicine, Karolinska Institutet, Stockholm, Sweden; ${ }^{4}$ Medical Affairs, US Nestlé Health Science, Bridgewater, MA, USA; ${ }^{5}$ Commercial and Medical Affairs, Pharmaceuticals, Nestlé Health Science, Bridgewater, MA, USA

Correspondence: Mark Nuijten Email mark@a2m.nl
Background: Obesity is a disease associated with high direct medical costs and high indirect costs resulting from productivity loss. The high prevalence of obesity generates the need for payers to identify cost-effective weight loss approaches. Among various weight management techniques, the OPTI (Optifast ${ }^{\mathbb{R}}$ ) program is a clinically recognised total meal replacement diet that can lead to significant weight loss and reduction in complications. This study's objective is to assess OPTI program's cost-effectiveness in Switzerland in comparison to "no intervention" and pharmacotherapy.

Methods: An event-driven decision-analytic model was used to estimate the payer's cost savings through the reimbursement of OPTI program over a 1-year period as well as a lifetime in Switzerland. The analysis was performed on a broad population of people with obesity with a body mass index (BMI) higher than $30 \mathrm{~kg} / \mathrm{m}^{2}$ following the OPTI program vs two comparators (liraglutide and "no intervention"). The model incorporated a higher risk of complications due to an increased BMI and their related healthcare costs. Data sources included published literature, clinical trials, official Swiss price/tariff lists and national population statistics. The primary perspective was that of a Swiss payer. Scenario analyses - for example, for patients with existing complications (such as myocardial infarction, stroke, type 2 diabetes mellitus) or severe obesity - were conducted to test the robustness of the results.

Results: The OPTI program results in cost savings of CHF 20,886 ( $€ 18,724)$ and $\mathrm{CHF}$ $15,382$ ( $€ 13,790)$ per person compared with "no intervention" and liraglutide $3 \mathrm{mg}$, respectively. In addition, OPTI program led to 1.133 and 0.734 quality-adjusted life years (QALYs) gained respectively against its comparators. Scenario analyses showed similar outcomes with cost savings and QALYs gained.

Conclusion: OPTI program is a dominant strategy compared to "no intervention" and liraglutide $3 \mathrm{mg}$ as it leads to both cost savings and QALY gain. Therefore, reimbursing the OPTI program for patients with obesity would be cost-effective for Swiss payers.

Keywords: obesity, cost-effectiveness, OPTI program, total meal replacement

\section{Background}

Obesity is a chronic disease characterised by an increase of body fat stores. ${ }^{1}$ In adults, obesity is defined as body mass index higher than or equal to $\mathrm{kg} / \mathrm{m}^{2}$ (BMI $\geq$ $30 \mathrm{~kg} / \mathrm{m}^{2}$ ). The main cause of obesity is energy imbalance (higher calories consumed than spent) continued for long enough to maintain the acquired higher energy needs of the overweight state.1 Progressive improvements in the standard 
of living, characterised by over-nutrition and sedentary lifestyle supplanting physical labour and regular physical activity, have contributed to the increasing prevalence of obesity in developed and developing countries.

Obesity is an important cause of premature mortality, morbidity, and lower quality of life, ${ }^{2}$ with severe consequences for persons and society. ${ }^{3,4}$ Already in 2010, overweight and obesity were estimated to cause 3.4 million deaths, $3.9 \%$ of years of life lost and $3.8 \%$ of disability adjusted life years (DALYs) globally. ${ }^{5}$ A high BMI is indeed linked to a higher risk of diseases like type 2 diabetes mellitus (T2DM), cardiovascular disease (eg myocardial infarction, MI; stroke) and some types of cancers. Specifically, it has been estimated that $44 \%$ of diabetes cases, $23 \%$ of coronary heart disease cases, and $7 \%$ to $41 \%$ of certain types of cancer cases are linked with overweight and obesity. ${ }^{6}$

The increasing clinical burden of obesity and its possible complications also leads to an economic burden resulting from direct medical costs and indirect costs due to lost productivity. ${ }^{78}$ USA data show that medical costs resulting from obesity, eg prescription drugs and hospitalizations, are substantially higher in obese persons than in people with normal weight, and correspond to $21 \%$ of annual US healthcare expenditure (US\$190 billion). ${ }^{9}$ Eighty-five percent of the obesity costs are attributable to five diseases: hypertension, T2DM, coronary artery disease, hyperlipidemia, and stroke. ${ }^{10,12}$ A review study conducted in eight Western European countries estimated incremental annual direct healthcare costs due to obesity ranging from $€ 117$ to $€ 1,873$ per person. ${ }^{12}$

In addition, reduced productivity due to obesity leads to an economic burden for employers. ${ }^{13,14}$ Finkelstein et al reported that the annual cost of obesity (the combined costs of medical expenditure and lost productivity) among full-time employees was estimated at US\$73.1 billion. ${ }^{15}$ Although persons with BMI $>35 \mathrm{~kg} / \mathrm{m}^{2}$ represented $37 \%$ of the obese population, they were responsible for $61 \%$ of excess lost productivity costs.

Picot assessed the clinical effectiveness and costeffectiveness of bariatric surgery for obesity. ${ }^{16}$ The population comprised adult patients with body mass index $(\mathrm{BMI})>$ or $=30$ and young obese people. In the economic model, the analysis was developed for three patient populations, those with $\mathrm{BMI}>$ or $=40$; $\mathrm{BMI}>$ or $=30$ and $<40$ with Type 2 diabetes at baseline; and BMI $>$ or $=30$ and $<35 \mathrm{~kg} / \mathrm{m}^{2}$. For morbid obesity, incremental costeffectiveness ratios (ICERs) (base case) ranged between
2,000 GBP and 4,000 GBP per QALY gained. This study shows that bariatric surgery appears to be a clinically effective and cost-effective intervention for moderately to severely obese people compared with non-surgical interventions.

Hoerger also analyzed the cost-effectiveness of bariatric surgery in severely obese (BMI $>35 \mathrm{~kg} / \mathrm{m}^{2}$ ) adults who have diabetes, using a validated diabetes cost-effectiveness model in the US setting. ${ }^{17}$ Bypass surgery had costeffectiveness ratios of US\$ 7,000/QALY and US\$ 12,000/QALY for severely obese patients with newly diagnosed and established diabetes, respectively. Banding surgery had cost-effectiveness ratios of $\$ 11,000 /$ QALY and $\$ 13,000 / \mathrm{QALY}$ for the respective groups.

In Switzerland, overweight and obesity occur in more than $37 \%$ of the population older than 15 years. ${ }^{18}$ Obesityrelated expenditures for payers were estimated to vary between CHF 2,691 million and CHF 3,229 million, representing the $2.3-3.5 \%$ of total health-care expenditures in $2005 .{ }^{19}$ Given this clinical and economic burden, it is of major interest for healthcare decision-makers to identify interventions aiming to prevent and treat obesity.

Meal replacement programs have been demonstrated to be not only effective but even sustainable in the long-term, as they help to lose more weight than other interventions and facilitate weight maintenance. ${ }^{20,21}$ Among those, OPTI (Optifast ${ }^{\circledR}$ ) program is an effective meal replacement weight loss treatment. ${ }^{22-25}$ The reduction of obesity and its clinical complications may lead to a reduction of direct medical costs (for payers) and indirect costs due to productivity loss (for employers). A previous health economic study by our group, indeed showed that OPTIFAST leads to cost savings of USD 9,285 per class I and II obese patient (BMI $30-39.9 \mathrm{~kg} / \mathrm{m}^{2}$ ) as compared to liraglutide over a period of 3 years, whereas the incremental costeffectiveness ratio is USD 6,475 per QALY compared to "no intervention". ${ }^{26}$

The objective of this health economic model is to assess OPTI program's cost-effectiveness in Switzerland in 2019.

\section{Methods}

\section{Framework}

An event-driven decision analytic model was used to estimate the cost-effectiveness of OPTI program in a Swiss setting. The assumption behind the model is that weight loss (expressed as "BMI reduction") leads to a reduction of the risk of developing 
complications of obesity listed in Table 1, which translates in a reduction of healthcare costs and lost productivity. ${ }^{27}$

The data sources include published literature, clinical trials, official Swiss price/tariff lists, and national population statistics. Costs in the model are expressed in 2019 CHF. Older costs were adjusted to the 2019 level by using an inflation correction. ${ }^{28}$ The Swiss health economic guidelines do not provide guidance on discounting. ${ }^{29}$

Table I Relative Risks for Complications in Subjects with Overweight and Obesity (Age 40) Compared to Normal Weight Subjects. ${ }^{27}$

\begin{tabular}{|l|c|c|c|c|}
\hline \multirow{2}{*}{ Complication } & \multicolumn{2}{|c|}{ Overweight } & \multicolumn{2}{c|}{ Obese } \\
\cline { 2 - 5 } & Male & Female & Male & Female \\
\hline Myocardial infarction & 1.37 & 1.45 & 2.14 & 2.38 \\
\hline Angina pectoris & 1.37 & 1.45 & 2.14 & 2.38 \\
\hline Chronic heart failure & 1.18 & 1.21 & 1.48 & 1.57 \\
\hline Other chronic heart disease & 1.37 & 1.45 & 2.14 & 2.38 \\
\hline Stroke & 1.10 & 1.12 & 1.25 & 1.29 \\
\hline Hypertension & 1.00 & 1.00 & 2.14 & 1.84 \\
\hline Diabetes & 2.78 & 2.86 & 11.49 & 11.17 \\
\hline Arthrosis hip & 1.22 & 1.88 & 4.50 & 4.50 \\
\hline Arthrosis knee & 1.22 & 1.22 & 1.61 & 1.61 \\
\hline Dorsopathy & 1.17 & 1.17 & 1.47 & 1.47 \\
\hline Cancer rectum & 1.11 & 1.13 & 1.27 & 1.32 \\
\hline Cancer colon & 1.20 & 1.23 & 1.54 & 1.64 \\
\hline Cancer breast & $\mathrm{NA}$ & 1.12 & $\mathrm{NA}$ & 1.31 \\
\hline Cancer prostate & 1.13 & $\mathrm{NA}$ & 1.34 & $\mathrm{NA}$ \\
\hline Cancer kidney & 1.40 & 1.40 & 2.23 & 2.23 \\
\hline Cancer endometrium* & $\mathrm{NA}$ & 1.59 & $\mathrm{NA}$ & 2.52 \\
\hline Cancer oesophagus* & 1.00 & 1.00 & 1.21 & 1.20 \\
\hline Cancer pancreas* & 1.00 & 1.00 & 2.29 & 1.60 \\
\hline Gall bladder disease* & 1.00 & 1.00 & 2.38 & 2.32 \\
\hline Back pain* & 1.00 & $2.8 \mathrm{I}$ & $2.8 \mathrm{I}$ \\
\hline Asthma* & 1.00 & 1.43 & 1.78 \\
\hline Pulmonary embolus* & 1.00 & 3.61 & 3.51 \\
\hline Coronary artery disease & 2.14 & 2.38 \\
\hline Notes No dat for ovewg & 1.00 \\
\hline
\end{tabular}

Notes: *No data for overweight and obesity in New Zealand report but based on internal Scoping Review. ${ }^{27}$

Abbreviation: NA, Not Applicable.
Therefore, a discount rate of $3.0 \%$ was applied to both costs and outcomes similarly to other recent costeffectiveness publications for Switzerland. ${ }^{30,31}$

\section{Model Design}

Figure 1 describes the structure of the model. The model contemplates two groups of patients: individuals with class I (BMI $\left.\geq 30 \mathrm{~kg} / \mathrm{m}^{2}\right)$ and class II (BMI $\left.\geq 35 \mathrm{~kg} / \mathrm{m}^{2}\right)$ obesity and, separately, individuals with class III obesity (BMI $\geq$ $40 \mathrm{~kg} / \mathrm{m}^{2}$ ). Both groups may experience an initial BMI reduction. Subsequently, subjects may regain weight with a consequent BMI increase, leading to a higher probability of health complications, or maintain the achieved weight loss with reduced risk of complications. It is important to note that in the model, weight gain itself does not have economic consequences. The cost drivers of the model are only the complications of obesity. The base case analysis was based on the assumption that patients have not developed any complication at the time of entering the model.

\section{Population and Comparator}

"No intervention" and liraglutide 3mg, an anti-obesity medication, were used as comparators to OPTI program in both groups, while bariatric surgery was additionally used only for subjects with severe (class III) obesity (Figure 1), as recommended in clinical guidelines.

We modelled a specific age cohort of 42 and $73.7 \%$ females based on epidemiologic data from Bischoff's study, which is the primary trial of OPTI program and the base of the current model. ${ }^{23}$

The study by Pi-Sunyer (2015), from which we extracted the effectiveness of the comparator liraglutide $3 \mathrm{mg}$, consisted of a similar population (average age 45.1 years; $78.5 \%$ females). ${ }^{32}$

\section{Perspective and Time Horizon}

This analysis was conducted from the perspective of the healthcare payer (private insurance), therefore accounting only for direct medical costs, in Switzerland in 2019. A second (scenario) analysis was performed from the societal perspective, in this case also including indirect costs due to productivity loss.

As obesity is a chronic condition, the base case model contemplates a lifetime time horizon and assumes a life expectancy of 84 years. ${ }^{33}$ To test the robustness of the extrapolated long-term data, a scenario analysis was performed to assess the impact of OPTI program over a 10-year time horizon. 


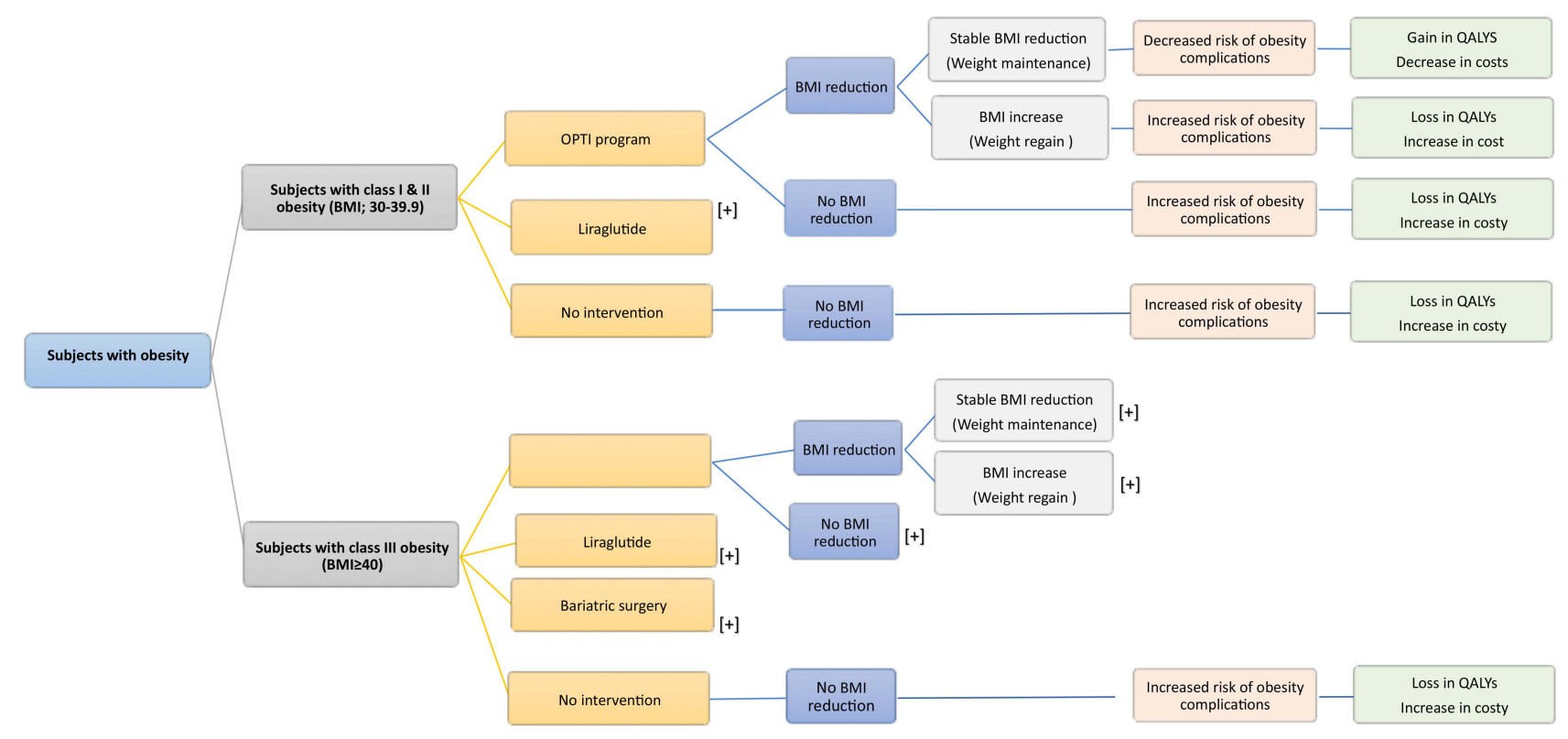

[+]: Diagram continues in a similar way as above

Figure I Structure of the model.

\section{Clinical and Economic Outcomes}

Clinical outcomes were measured in terms of life years (LYs) and quality adjusted life years (QALYs) lost by an individual due to adverse health outcomes or gained as a result of one of the treatments. The model included direct medical costs associated with resource utilisation in each of the obesity treatment options (OPTI program, liraglutide $3 \mathrm{mg}$, and bariatric surgery). Potential complications of each treatment were also included.

From the possible indirect costs, only the loss of productivity was considered and only in the scenario analysis from the societal perspective. Any other non-medical cost (eg transportation) was not included in the primary analysis (payer perspective) because it was not relevant nor in the second (societal perspective) due to lack of data.

\section{Data Sources}

\section{Probabilities}

\section{Incidence of Complications and Mortality Due to} Overweight/Obesity

A report by the Health Research Council of New Zealand yields gender and age-specific data on the annual incidence of complications and mortality, and increased risk for patients with excess weight and obesity. ${ }^{27}$ In the current health economic model, we assumed that clinical data from the New Zealand report can also be applied to the Swiss population.
Table 1 shows risks of all complications in the defined study population, age 44 . Only complications leading to direct (medical) and indirect (productivity) costs or QALYs loss are included in the model, therefore ignoring intermediate outcomes (eg laboratory blood showing high cholesterol levels).

\section{Effectiveness of the Obesity Treatments OPTI Program}

Two studies assessed the effectiveness of OPTI program in terms of weight loss. The first, conducted in Germany by Bischoff et al in 2012, assessed the effectiveness of the 52week OPTI program, composed of 12 weeks of a total meal replacement, low-calorie diet with additional interventions to enhance nutritional education, increased physical activity, and modified eating behaviour. ${ }^{23}$ Intention-to -treat (ITT) analysis revealed a BMI reduction of $7.0 \mathrm{~kg}$ in women and $8.0 \mathrm{~kg}$ in men. ${ }^{23}$

The second, by Wadden et al, revealed that OPTI program achieved a long-term weight reduction in the US population. Three years after the end of the program, $53 \%$ of patients maintained a weight loss of at least $5 \%$, while $35 \%$ of patients maintained a weight loss of at least $10 \%{ }^{34}$ These trends were observed even 4 and 5 years after the end of the OPTI program, but the declining sample sizes prevented definitive assessments. ${ }^{34}$

The base case analysis in the present study is based on data from the Bischoff study ${ }^{23}$ because of the large sample 
size (8,296 subjects) and the fact that it included German patients (Table 3), who were more similar to the Swiss population than the US as far as concerns culture and eating habits. Conversely, the extrapolation beyond 1-year followup was based on long-term data from Wadden. ${ }^{23}$ The BMI values from both clinical trials were adjusted linearly to an initial BMI of $35 \mathrm{~kg} / \mathrm{m}^{2}$ and $45 \mathrm{~kg} / \mathrm{m}^{2}$, respectively, for mild (class I and II) and severe (class III) obesity.

The base case analysis is based on efficacy data from the clinical studies for the OPTI program. However, in Switzerland, OPTI program LCD is available only as a total and partial meal replacement dietary regime without the additional counselling and physical activity components of the OPTI program. Since there are no underlying data to show efficacy for only OPTI program without the program, we added scenario analyses based on $5 \%$ and $10 \%$ reduction of efficacy for OPTI program during the first 2 years of the model when the active program is continued and the counselling and physical activity occurs. We assumed no difference in subsequently regaining weight.

\section{Liraglutide $3 \mathrm{Mg}$}

Liraglutide $3 \mathrm{mg}$ is an anti-obesity medication launched in Europe in March 2015. Liraglutide is a GLP1 analogue with the benefit of weight loss, administered at a dose of $3.0 \mathrm{mg}$ once a day with a subcutaneous injection. ${ }^{32}$ The product aims to achieve at least $5 \%$ loss of the initial body weight in 12 weeks of therapy; otherwise, it should be discontinued. ${ }^{35-37}$

The study by Pi-Sunyer (2015) showed that liraglutide $3 \mathrm{mg}$ resulted in an average loss of $3.0 \mathrm{BMI}$ units compared to $1.0 \mathrm{BMI}$ unit for the placebo in 56 weeks. ${ }^{32}$ In the present model, the BMI values from the clinical trials were adjusted linearly to an initial BMI of 35 and 45, for mild and severe obesity, respectively.

Compared to the placebo arm, a substantially higher incidence of adverse health outcomes was observed with liraglutide $3 \mathrm{mg} .{ }^{32}$ All of these adverse events, nausea $(40.2 \%$ vs $14.7 \%)$, diarrhoea ( $20.9 \%$ vs $9.3 \%)$, vomiting $(16.3 \%$ vs $4.1 \%)$, and dyspepsia $(9.5 \%$ vs $3.1 \%)$, were included in the model.

The Wadden study ${ }^{38}$ confirmed the long-term efficacy of liraglutide $3 \mathrm{mg}$ on weight loss (81.4\% of participants receiving liraglutide $3 \mathrm{mg}$ maintained the $>5 \%$ initial body weight loss, compared to $48.9 \%$ receiving placebo) as well as a higher incidence of gastrointestinal disorders. ${ }^{38}$

\section{Bariatric Surgery}

Clegg performed a systematic review to assess the costeffectiveness of surgery for people with morbid obesity. ${ }^{10,12}$ Patients eligible for surgery were those with class II (BMI $>35 \mathrm{~kg} / \mathrm{m}^{2}$ ) obesity associated with serious comorbidity or class III (BMI $>40 \mathrm{~kg} / \mathrm{m}^{2}$ ) obesity, with a record of failure of previous nonsurgical interventions. The three studies included in the review compared different surgical interventions (horizontal gastroplasty, ${ }^{39,40}$ jejunoileostomy, ${ }^{41,42}$ and either vertical banded gastroplasty, gastric banding, or gastric bypass ${ }^{43}$ ) with nonsurgical management. ${ }^{44}$ The base case analysis of the current model is based on the average BMI values of the three surgery options (Table 2) and includes the incidence of re-operation of $2.2 \%$ based on the SOS study reported by Clegg. ${ }^{45}$

To be conservative, only few perioperative complications such as abscess $(7 \%)$, atelectasis/pneumonia (4\%), wound infection (4-6\%), pulmonary complications (3-

Table 2 Efficacy of Interventions Expressed in BMI/Year

\begin{tabular}{|c|c|c|c|c|c|c|c|}
\hline \multirow[b]{2}{*}{ Year } & \multicolumn{3}{|c|}{ BMI Mild Obesity } & \multicolumn{4}{|c|}{ BMI Severe Obesity } \\
\hline & $\begin{array}{c}\text { OPTI } \\
\text { Program }^{23,24}\end{array}$ & $\begin{array}{c}\text { Liraglutide } \\
3 \mathrm{mg}^{32,38}\end{array}$ & $\begin{array}{c}\text { No } \\
\text { Intervention }\end{array}$ & $\begin{array}{c}\text { OPTI } \\
\text { Program }^{23,24}\end{array}$ & $\begin{array}{c}\text { Liraglutide } \\
3 \mathrm{mg}^{32,38}\end{array}$ & $\begin{array}{c}\text { No } \\
\text { Intervention }\end{array}$ & Surgery ${ }^{10,12}$ \\
\hline Year I & 35 & 35 & 35 & 45 & 45 & 45 & 45 \\
\hline Year 2 & 28.64 & 32.81 & 35 & 42.19 & 36.82 & 45 & 33 \\
\hline Year 3 & 32 & 32.88 & 35 & 42.28 & 41.14 & 45 & 37 \\
\hline Year 4 & 32.56 & 32.95 & 35 & 42.37 & 41.87 & 45 & 41 \\
\hline Year 5 & 32.87 & 33.02 & 35 & 42.46 & 42.27 & 45 & 45 \\
\hline Year 6 & 33.18 & 33.1 & 35 & 42.55 & 42.66 & 45 & 45 \\
\hline Year 7 & 33.49 & 33.17 & 35 & 42.64 & 43.06 & 45 & 45 \\
\hline Year 8 & 33.8 & 33.24 & 35 & 42.73 & 43.46 & 45 & 45 \\
\hline Year 10* & 34.11 & 33.31 & 35 & 42.83 & 43.86 & 45 & 45 \\
\hline
\end{tabular}

Notes: *Assuming that after 10 years BMI remains unchanged. 
Table 3 Disutilities of Adverse Events and Bariatric Surgery

\begin{tabular}{|l|l|l|l|l|}
\hline $\begin{array}{l}\text { Adverse } \\
\text { Events }\end{array}$ & Utility & SE & Source & Assumption \\
\hline Nausea & -0.0408 & 0.01543 & Nafees $^{47}$ & \\
\hline Vomiting & -0.0408 & 0.01543 & Nafees $^{47}$ & \\
\hline Diarrheal & -0.0468 & 0.01553 & Nafees $^{47}$ & \\
\hline Dyspepsia & -0.0408 & 0.01543 & Nafees $^{47}$ & Assume vomiting \\
\hline $\begin{array}{l}\text { Bariatric } \\
\text { surgery }\end{array}$ & -0.0408 & 0.01543 & Nafees $^{47}$ & Assume vomiting \\
\hline
\end{tabular}

$6.2 \%)$, and hepatic dysfunction $(1.5 \%)^{39,42,45}$ were included in the current model, ${ }^{10}$ therefore ignoring other possible adverse health outcomes, such as vomiting, anaemia due to lack absorption of iron, dumping syndrome, and vitamin B12 and calcium deficiency. ${ }^{46}$

\section{Utilities}

The model includes utilities lost because of complications of obesity (adverse events) or gained as a result of the treatment and weight loss. Few assumptions were made:

- The utilities linked to the complications of obesity were considered separately between the first year and subsequent years (Table 3 ) due to possible changes from one year to another (eg the utility of stroke in first year is lower than in the following years);

- The utility for patients with a complication at baseline is based on the assumption that these patients have suffered from that complication for at least one year, and therefore, utility is based on the value for subsequent years ( $>$ year 1 ).

- Adverse events of drugs and complications of bariatric surgery: the base case analysis is based on a temporary disutility for duration of 2 months (Table 4). Disutilities were derived from studies by Nafees and Restelli. ${ }^{4,48}$

- The model also includes utility gain from weight loss. The Quality-of-Life study by Lane provided data on utilities related to BMI loss and gain. ${ }^{49}$ This study estimated utility values for hypothetical health states that describe differences in weight and quality of life associated with T2DM. For every increase of $1 \mathrm{~kg} / \mathrm{m}^{2}$ BMI, there was an associated decrease in utility of 0.0472 (95\% CI: $0.0375,0.0569)$ and for every decrease of $1 \mathrm{~kg} / \mathrm{m}^{2}$ BMI there was an associated increase in utility of 0.0171 (95\% CI: 0.0103, 0.0238). An older study by Hakim provided data on change in utility per $\mathrm{kg} / \mathrm{m}^{2}$ : Time-Trade-Off with 0.017 change in utility due to change per $\mathrm{kg} / \mathrm{m}^{2.50}$

- QALYs related to oncologic events are already discounted. Therefore, the years after the first are already considered in the reported figure.

\section{Costs and Health Care Utilisation OPTI Program}

The recommended OPTI program diet in Switzerland has the following structure: an initial 13 weeks of total meal replacement phase with 4 to 5 (average 4.5) OPTI servings daily, followed by 8 weeks of 2 OPTI servings daily, and finally, 31 weeks with one OPTI program meal replacement per day, for a total of 52 weeks. Hence, the consumption of OPTI program totals 738.5 servings, with a calculated cost of $\mathrm{CHF} 3,695$ at public price of $\mathrm{CHF}$ 5.00 per sachet.

In our assumption, the cost is split between a healthcare payer at $90 \%$ (CHF 4.5 per OPTI program meal replacement, total CHF 3,323.25) and a patient at 10\% (CHF 0.5, for a total of CHF 369.25) following the usual drug and medical nutrition reimbursement rules in Switzerland.

We exclude any related costs for visits as an additional program is not yet available in Switzerland.

\section{Liraglutide $3 \mathrm{Mg}$}

We assumed that after 12 weeks, only responders $(63,2 \%)$ continue treatment with liraglutide $3 \mathrm{mg}$. The price of the medication is CHF 351.90 for a pack of 5 units of $3 \mathrm{~mL}$ with a total of $90 \mathrm{mg}$ per pack. ${ }^{66}$ In the base case analysis, we also assume $90-10 \%$ split between a healthcare payer and patient, whereas a scenario analysis is based on 80 $20 \%$ split. The daily dose is $3 \mathrm{mg}$, which leads to $90 \mathrm{mg}$ over 30 days monthly period with a monthly cost of CHF 351.90. This daily dose is reached after titration of 4 weeks. The base case analysis assumed one visit for each adverse event, but we exclude any related costs for visits to remain conservative versus OPTI program.

\section{Bariatric Surgery}

The costs of bariatric surgery (CHF 16,934) are based on Schneider's paper, "Cost of Obesity in Switzerland in 2012", 67 which was updated in 2019 using inflation correction. The analysis assumes three doctor's visits in 
Table 4 Utilities Linked to the Complications of Obesity

\begin{tabular}{|c|c|c|c|c|}
\hline Complications & Model Year & $\begin{array}{l}\text { Mean } \\
\text { Utility }\end{array}$ & Source & Assumption \\
\hline \multirow[t]{2}{*}{ AMI } & Year 1 & 0.812 & \multirow[t]{2}{*}{ Grima $^{51}$} & \\
\hline & $>$ year I & 0.854 & & \\
\hline \multirow[t]{2}{*}{ Other CHD } & Year I & 0.704 & \multirow[t]{2}{*}{ McQueen ${ }^{52}$} & \\
\hline & $>$ yearl & 0.699 & & \\
\hline \multirow[t]{2}{*}{$\mathrm{CHF}$} & Year I & 0.636 & \multirow[t]{2}{*}{ Marra $^{53}$} & \\
\hline & $>$ yearl & 0.636 & & \\
\hline \multirow[t]{2}{*}{ Stroke } & Year I & 0.736 & \multirow[t]{2}{*}{ Grima $^{51}$} & \\
\hline & $>$ yearl & 0.854 & & \\
\hline \multirow[t]{2}{*}{ Diabetes male } & Year I & 0.940 & \multirow[t]{2}{*}{ Lachaine $^{54}$} & \\
\hline & > yearl & 0.940 & & \\
\hline \multirow[t]{2}{*}{ Diabetes female } & Year I & 0.950 & \multirow[t]{2}{*}{ Lachaine $^{54}$} & \\
\hline & > yearl & 0.950 & & \\
\hline \multirow{2}{*}{$\begin{array}{l}\text { Arthrosis of the } \\
\text { hip }\end{array}$} & Year I & 0.840 & \multirow[t]{2}{*}{ Marsh $^{55}$} & \\
\hline & > yearl & 0.840 & & \\
\hline \multirow{2}{*}{$\begin{array}{l}\text { Arthrosis of the } \\
\text { knee }\end{array}$} & Year I & 0.840 & \multirow[t]{2}{*}{$\operatorname{Marsh}^{55}$} & \multirow[t]{2}{*}{ AO hip } \\
\hline & > yearl & 0.860 & & \\
\hline \multirow[t]{2}{*}{ Dorsopathies } & Year 1 & 0.840 & \multirow[t]{2}{*}{$\mathrm{Marsh}^{55}$} & \multirow[t]{2}{*}{ AO hip } \\
\hline & $>$ yearl & 0.840 & & \\
\hline \multirow{2}{*}{$\begin{array}{l}\text { Cancer of } \\
\text { rectum }\end{array}$} & Year I & 0.947 & \multirow[t]{2}{*}{ Blank $^{56}$} & \multirow[t]{2}{*}{ Colorectal } \\
\hline & > yearl & 0.000 & & \\
\hline \multirow[t]{2}{*}{ Cancer of colon } & Year 1 & 0.947 & \multirow[t]{2}{*}{ Blank $^{56}$} & \\
\hline & $>$ yearl & 0.000 & & \\
\hline \multirow[t]{2}{*}{ Cancer of breast } & Year I & 13.169 & \multirow[t]{2}{*}{ Blank $^{57}$} & \\
\hline & $>$ yearl & 0.000 & & \\
\hline \multirow{2}{*}{$\begin{array}{l}\text { Cancer of } \\
\text { prostate }\end{array}$} & Year I & 7.545 & \multirow[t]{2}{*}{ Koerber $^{58}$} & Colorectal \\
\hline & $>$ yearl & 0.000 & & \\
\hline Cancer of & Year I & 1.180 & $\operatorname{Martin}^{59}$ & \\
\hline kidney & > yearl & 0.000 & & \\
\hline Cancer of & Year I & 8.900 & $\mathrm{Kwon}^{60}$ & \\
\hline endometrium & $>$ yearl & 0.000 & & \\
\hline ACS & Year I & 0.875 & Grima $^{51}$ & \\
\hline & $>$ yearl & 0.875 & & \\
\hline Hypertension & Year I & 0.980 & Lachaine $^{54}$ & \\
\hline male & > yearl & 0.980 & & \\
\hline
\end{tabular}

(Continued)
Table 4 (Continued).

\begin{tabular}{|c|c|c|c|c|}
\hline Complications & Model Year & $\begin{array}{c}\text { Mean } \\
\text { Utility }\end{array}$ & Source & Assumption \\
\hline \multirow{2}{*}{$\begin{array}{l}\text { Hypertension } \\
\text { female }\end{array}$} & Year I & 1.00 & \multirow[t]{2}{*}{ Lachaine ${ }^{54}$} & \\
\hline & > yearl & 1.00 & & \\
\hline \multirow[t]{2}{*}{ Angina } & Year I & 0.709 & \multirow[t]{2}{*}{ Marra $^{53}$} & \\
\hline & $>$ yearl & 0.709 & & \\
\hline \multirow[t]{2}{*}{ GBD } & Year I & 0.440 & \multirow[t]{2}{*}{ Adam $^{61}$} & \\
\hline & $>$ yearl & 0.440 & & \\
\hline \multirow[t]{2}{*}{ Back pain } & Year I & 0.840 & \multirow[t]{2}{*}{ Marsh $^{55}$} & \multirow[t]{2}{*}{ AO hip } \\
\hline & $>$ yearl & 0.840 & & \\
\hline \multirow[t]{2}{*}{ Asthma } & Year I & 0.740 & \multirow[t]{2}{*}{ McKeever ${ }^{62}$} & \\
\hline & $>$ yearl & 0.740 & & \\
\hline \multirow{2}{*}{$\begin{array}{l}\text { Pulmonary } \\
\text { embolus }\end{array}$} & Year I & -0.022 & \multirow[t]{2}{*}{ Coyle $^{63}$} & \\
\hline & $>$ yearl & 0.000 & & \\
\hline \multirow{2}{*}{$\begin{array}{l}\text { Cancer } \\
\text { pancreatic }\end{array}$} & Year I & 1.497 & \multirow[t]{2}{*}{ Gurusamy $^{64}$} & \\
\hline & $>$ yearl & 0.000 & & \\
\hline \multirow{3}{*}{$\begin{array}{l}\text { Cancer } \\
\text { oesophagus }\end{array}$} & Year I & 9.062 & \multirow[t]{3}{*}{ Filby ${ }^{65}$} & \\
\hline & $>$ yearl & 0.000 & & \\
\hline & $>$ yearl & 0.000 & & \\
\hline \multirow[t]{2}{*}{ Death } & Year I & 0.000 & & \\
\hline & $>$ yearl & 0.000 & & \\
\hline
\end{tabular}

first year and one visit every next year for medical management after surgery. The cost of one consultation, CHF 237 in 2008, was updated to 2019. We assumed that the surgeon's fee is included in the total cost of surgery. The cost for adverse events of drugs and complications of bariatric surgery were only included for the duration of 2 months period.

\section{Obesity Complications}

The medical costs of complications of obesity for Switzerland were derived from published literature (Table 5). The cost in the first year was calculated separately from subsequent years, as it was often higher than the latter.

The cost for patients with a complication at the baseline was based on the assumption that patients had suffered from that complication for at least one year, and therefore, 
Table 5 Costs of Complications Due to Overweight/Obesity

\begin{tabular}{|c|c|c|c|c|}
\hline Complication & $\begin{array}{l}\text { Model } \\
\text { Year }\end{array}$ & $\begin{array}{l}\text { Mean } \\
\text { Cost } \\
(\mathrm{CHF})\end{array}$ & Source & Assumption \\
\hline \multirow[t]{2}{*}{ AMI } & Year I & 20,366 & \multirow[t]{2}{*}{ Polock ${ }^{68}$} & \\
\hline & $>$ yearl & 2,696 & & \\
\hline \multirow[t]{2}{*}{ Angina } & Year I & 11,035 & \multirow[t]{2}{*}{ Polock $^{68}$} & \\
\hline & $>$ yearl & 2,742 & & \\
\hline \multirow[t]{2}{*}{ Other CHD } & Year I & 13,633 & \multirow[t]{2}{*}{ Polock $^{68}$} & \\
\hline & $>$ yearl & 13,633 & & \\
\hline \multirow[t]{2}{*}{$\mathrm{CHF}$} & Year I & 32,098 & \multirow[t]{2}{*}{ Weber $^{69}$} & \\
\hline & $>$ yearl & 32,098 & & \\
\hline \multirow[t]{2}{*}{ Stroke } & Year I & 36,276 & \multirow[t]{2}{*}{ Polock ${ }^{68}$} & \\
\hline & $>$ yearl & 9,385 & & \\
\hline \multirow[t]{2}{*}{ ACS } & Year I & 6,187 & \multirow[t]{2}{*}{ Galani $^{70}$} & \\
\hline & $>$ yearl & 6,187 & & \\
\hline \multirow[t]{2}{*}{ Hypertension } & Year I & 1,689 & \multirow[t]{2}{*}{ Galani $^{70}$} & \\
\hline & $>$ yearl & 1,689 & & \\
\hline \multirow[t]{2}{*}{ Diabetes } & Year I & 6,631 & \multirow[t]{2}{*}{ Hubert $^{71}$} & \\
\hline & $>$ yearl & 6,631 & & \\
\hline \multirow[t]{2}{*}{ Arthrosis hip } & Year I & 1,039 & \multirow[t]{2}{*}{ Polock ${ }^{68}$} & \multirow{2}{*}{$\begin{array}{c}\text { Assume } \\
\text { neuropathy }\end{array}$} \\
\hline & $>$ yearl & 1,039 & & \\
\hline \multirow[t]{2}{*}{ Arthrosis knee } & Year I & 1,039 & \multirow[t]{2}{*}{ Polock ${ }^{68}$} & \multirow{2}{*}{$\begin{array}{c}\text { Assume } \\
\text { neuropathy }\end{array}$} \\
\hline & $>$ yearl & 1,039 & & \\
\hline \multirow[t]{2}{*}{ Dorsopathy } & Year I & 1,039 & \multirow[t]{2}{*}{ Polock $^{68}$} & \multirow{2}{*}{$\begin{array}{c}\text { Assume } \\
\text { neuropathy }\end{array}$} \\
\hline & $>$ yearl & 1,039 & & \\
\hline \multirow[t]{2}{*}{ Cancer rectum } & Year I & 60,774 & \multirow[t]{2}{*}{ Blank $^{56}$} & \\
\hline & $>$ yearl & 0 & & \\
\hline \multirow[t]{2}{*}{ Cancer colon } & Year I & 60,774 & \multirow[t]{2}{*}{ Blank $^{56}$} & \\
\hline & $>$ yearl & 0 & & \\
\hline \multirow[t]{2}{*}{ Cancer breast } & Year I & 49,433 & Blank $^{57}$ & \\
\hline & $>$ yearl & 0 & & \\
\hline Cancer & Yearl & 41,344 & Koerber ${ }^{58}$ & \\
\hline & $>$ yearl & 0 & & \\
\hline Cancer kidney & Year I & 77,433 & $\operatorname{Martin}^{59}$ & \\
\hline & $>$ yearl & 0 & & \\
\hline
\end{tabular}

(Continued)
Table 5 (Continued).

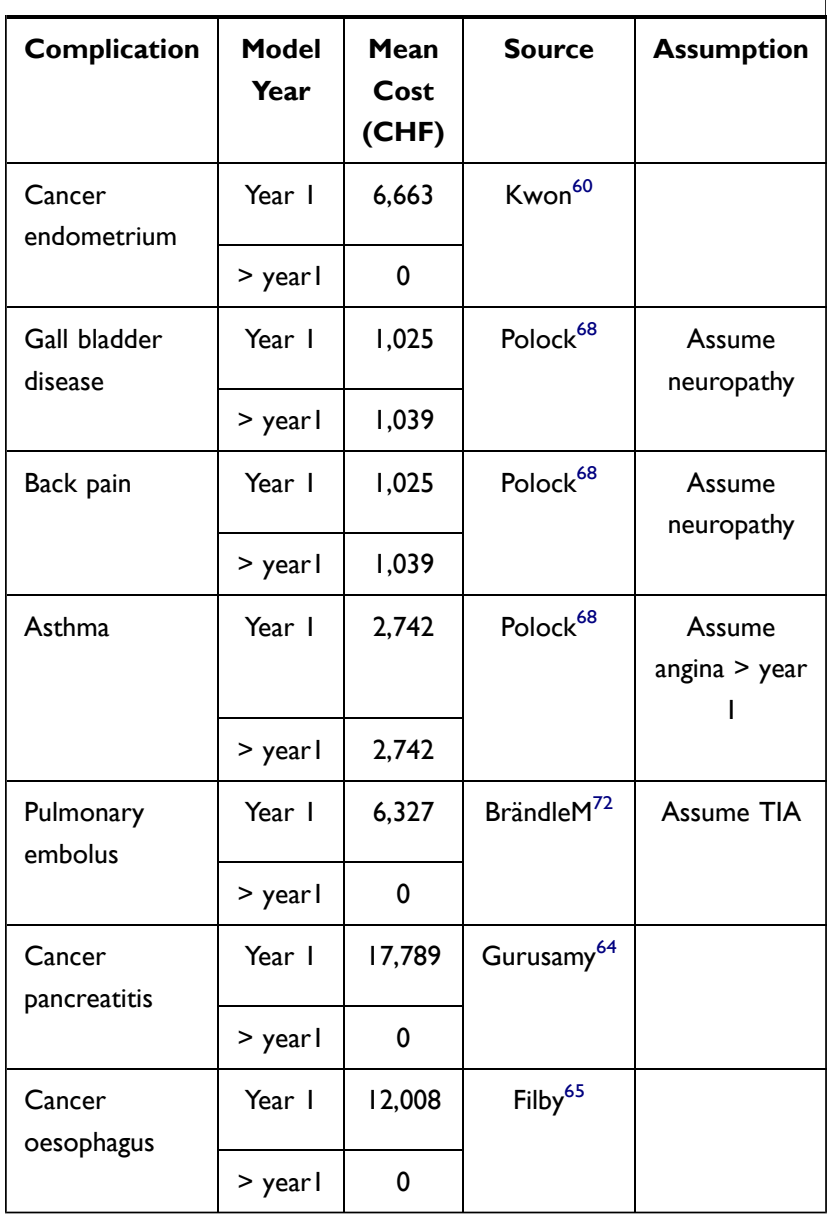

the cost was only based on value for subsequent years (> year 1).

Oncological costs for the first year were already discounted; therefore, a value equal to 0 was assigned to the following years.

\section{Indirect Costs}

Finkelstein et al calculated the total costs due to medical expenditures and productivity loss (including absenteeism and presenteeism) per capita in US employees with obesity, stratified for the grade of obesity. ${ }^{15}$ Annual additional missed workdays varied from 0.5 days for men who were overweight (BMI 25-29,9 kg/m²) to 5.9 days for men with severe obesity (class III, BMI $\geq 40 \mathrm{~kg} / \mathrm{m}^{2}$ ). Costs due to presentism were also substantially higher in obesity and they approximately doubled between each obesity class, varying from an estimate of 2.3 days for class I obesity to 21.9 days for patients with class III obesity. The average 
Swiss daily cost of work in 2019 (CHF 349.17) was multiplied by the expected days of lost productivity.

We assumed the productivity lost to be minimal for outpatient visits. On the other hand, for surgery, we calculated the missed days of work. For example, a gastric bypass requires up to 10 days of inpatient stay, with most patients unable to resume work until after one month following surgery.

\section{Results}

\section{Base Case Analysis}

The base case results for the mild (class I and II) obesity group are presented in Table 6. OPTI program is dominantly costeffective versus "no intervention" and liraglutide $3 \mathrm{mg}$, as it leads to cost savings and QALYs gain. We present monetary values in CHF and $€$ (exchange $1 €=\mathrm{CHF} 0.896$ ). ${ }^{73}$

More specifically, the completion of the OPTI program is expected to accrue CHF 533,499 ( $€ 478,274)$ total discounted costs over lifetime period, whereas "no intervention" and liraglutide $3 \mathrm{mg}$ are expected to accrue CHF 554,386 (€ 496,999) and CHF 548,881 (€ 492,064) total discounted costs, respectively. Consequently, the completion of the OPTI program leads to cost savings of CHF
20,886 ( $€ 18,724)$ and CHF 15,382 (€ 13,790) per person compared with "no intervention" and liraglutide $3 \mathrm{mg}$, respectively.

The discounted QALYs over lifetime period for OPTI program, "no intervention", and liraglutide $3 \mathrm{mg}$, are $18.456,17.322$, and 17.721, respectively, and consequently the completion of the OPTI program leads to gain 1.133 and 0.734 QALYs, respectively, against its comparator.

The analysis on the subgroup with severe (class III) obesity showed (Table 7) that absolute costs increase substantially for all treatments and QALYs are slightly reduced if red to the mild (class I and II) obesity group. Nevertheless, OPTI program remains dominant. When compared to the surgery (treatment option not considered for the group with mild obesity), the cost savings amounted to CHF 17,996 and the QALYs gained to 0.704 .

\section{Scenario Analysis}

When a societal perspective is adopted, savings are even higher: from of CHF 20,886 ( $€ 18,724)$ to CHF 69,851 ( $€$ $62,620)$ versus "no intervention" and from CHF 15,382 ( $€$ $13,790)$ to $\mathrm{CHF} 41,717$ (€ 37,399) versus liraglutide $3 \mathrm{mg}$ because of the reduction of indirect costs due to the productivity loss (Table 8).

Table 6 Base Case Results (Class I and II Obesity)

\begin{tabular}{|l|c|c|c|c|c|c|c|c|c|}
\hline Treatment & $\begin{array}{c}\text { Costs } \\
(\mathbf{C H F})\end{array}$ & $\begin{array}{c}\text { Costs } \\
(\boldsymbol{\epsilon})\end{array}$ & QALYs & LYG & $\begin{array}{c}\text { D Costs } \\
(\mathbf{C H F})\end{array}$ & $\begin{array}{c}\text { D Costs } \\
(\boldsymbol{\epsilon})\end{array}$ & D QALYs & D LYGs & ICER \\
\hline $\begin{array}{l}\text { "No } \\
\text { intervention" }\end{array}$ & 554,386 & 496,999 & 17.322 & 22.466 & $-20,886$ & $-18,724$ & 1.133 & $\begin{array}{c}0.193 \\
\text { OPTI program } \\
\text { dominant }\end{array}$ \\
\hline Liraglutide & 548,881 & 492,064 & 17.721 & 22.488 & $-15,382$ & $-13,790$ & 0.734 & 0.171 & OPTI dominant \\
\hline OPTI program & 533,499 & 478,274 & 18.456 & 22.659 & & & & & \\
\hline
\end{tabular}

Abbreviation: D, difference.

Table 7 Scenario Analysis for Severe (Class III) Obesity

\begin{tabular}{|c|c|c|c|c|c|c|c|c|c|}
\hline Treatment & $\begin{array}{l}\text { Costs } \\
\text { (CHF) }\end{array}$ & $\begin{array}{c}\text { Costs } \\
(€)\end{array}$ & QALYs & LYG & $\begin{array}{l}\text { D Costs } \\
\text { (CHF) }\end{array}$ & $\begin{array}{c}\text { D Costs } \\
(€)\end{array}$ & D QALYs & D LYGs & ICER \\
\hline $\begin{array}{l}\text { "No } \\
\text { intervention" }\end{array}$ & 708,521 & 635,179 & 15.990 & 20.600 & $-9,792$ & -8.778 & 0.734 & 0.055 & $\begin{array}{c}\text { OPTI program } \\
\text { dominant }\end{array}$ \\
\hline Liraglutide & 701,550 & 628,929 & 16.511 & 20.631 & $-2,721$ & -2.439 & 0.212 & 0.024 & $\begin{array}{c}\text { OPTI program } \\
\text { dominant }\end{array}$ \\
\hline Surgery & 716,725 & 642,534 & 16.020 & $20.34 I$ & $-17,996$ & -16.133 & 0.704 & 0.314 & $\begin{array}{c}\text { OPTI program } \\
\text { dominant }\end{array}$ \\
\hline OPTI program & 698,729 & 626,400 & $16.72 \mid$ & 20.655 & & & & & \\
\hline
\end{tabular}

Abbreviation: D, difference. 
Table 8 Scenario Analysis from the Society Perspective

\begin{tabular}{|l|c|c|c|c|c|c|c|c|c|}
\hline Treatment & $\begin{array}{c}\text { Costs } \\
(\mathbf{C H F})\end{array}$ & $\begin{array}{c}\text { Costs } \\
(\boldsymbol{\epsilon})\end{array}$ & QALYs & LYG & $\begin{array}{c}\text { D Costs } \\
(\mathbf{C H F})\end{array}$ & $\begin{array}{c}\text { D Costs } \\
(\boldsymbol{\epsilon})\end{array}$ & D QALYs & D LYGs & ICER \\
\hline $\begin{array}{l}\text { "No } \\
\text { intervention" }\end{array}$ & 930,861 & 834,503 & 17.322 & 22.466 & $-69,851$ & -62.620 & 1.133 & $\begin{array}{c}0.193 \\
\text { OPTI program } \\
\text { dominant }\end{array}$ \\
\hline Liraglutide & 902,727 & 809,282 & 17.721 & 22.488 & $-41,717$ & -37.399 & 0.734 & $\begin{array}{c}0.171 \\
\text { OPTI program } \\
\text { dominant }\end{array}$ \\
\hline OPTI & 861,010 & 771,883 & 18.456 & 22.659 & & & & & \\
\hline
\end{tabular}

Abbreviation: D, difference.

Other scenario analyses, with their definition and assumptions, are presented in Table A1 (Appendix). The results show that while OPTI program is dominant in each, the absolute outcomes are quite different.

For example, the lower survival after a MI or a stroke leads to substantial lower costs and lower QALYs for all treatment options. Therefore, cost savings and QALY gain for OPTI program versus "no intervention" and liraglutide $3 \mathrm{mg}$ in these cases are also lower. These results indicate that early obesity treatment before occurrence of complications is more cost-effective than later treatment, as expected in clinical practice.

On the other hand, the scenario analyses based on 5\% and $10 \%$ reduction of efficacy for OPTI program did not yield significantly different outcomes: OPTI program remains dominant and only leads to minimal changes in costs and QALYs.

\section{Discussion}

OPTI program is a total meal replacement diet for individuals with obesity indicated for chronic weight management in adults with an initial BMI of $30 \mathrm{~kg} / \mathrm{m}^{2}$ or greater (obese). Clinical data reveal that the consumption of OPTI program can lead to substantial weight loss. ${ }^{22-25}$

This analysis compared OPTI program to "no intervention" and liraglutide $3 \mathrm{mg}$ from a payer's (private insurance) perspective. Bariatric surgery was also considered an appropriate comparator for patients with class III obesity.

OPTI program was found to be a cost-effective intervention in reducing obesity, with its related clinical complications and medical costs, and increasing QALYs in Switzerland. Cost savings per person, starting from their 40s and continuing over a lifetime follow-up period, were respectively equal to CHF 20,886 ( $€ 18,724)$ and QALYs gained to 1.133 vs no intervention, and to CHF15,382 ( $€$ 13,790 ) and 0.734 vs liraglutide $3 \mathrm{mg}$. OPTI program was a dominant treatment option even when compared to bariatric surgery in patients with class III obesity, as well as in patients with class II obesity and comorbidities.

The societal perspective assumed in one of the scenario analyses leads to significantly higher cost savings than the payer's perspective used in the base case due to the inclusion of indirect costs. A lifetime time horizon was considered in order to capture all potential reduction in the risk factors associated with proper weight management. Intermediate lifetime horizon (eg 10 years), performed in the scenario analyses confirmed the robustness of the results.

Other scenario analyses assessed that the overall costeffectiveness for OPTI program was not greatly impacted through variation in parameters such as discount rate, mortality calculation or pre-existing patient comorbidities.

To compare the results of this model with other health economic studies in obesity in Switzerland, we reviewed the published economic literature on lifestyle interventions and found only one publication by Galani from 2007. ${ }^{70}$ Galani assessed the lifetime health and economic consequences of preventing and treating obesity with lifestyle intervention in Switzerland. They developed a Markov model to compare lifestyle intervention and standard care in overweight and obese people. The study did not report the overall lifetime costs, LYs, or QALYs for lifestyle intervention and standard care, but only the differences. Therefore, we can only compare these differences with our study. In the study by Galani ${ }^{70}$ the lifestyle intervention resulted in increased survival and improved quality of life, equivalent to a difference of $0.05 \mathrm{LY}$ and 0.33 QALY per person per year gained over lifetime. In the current model, the consumption of OPTI program leads to gain $0.193 \mathrm{LY}$ and 1.133 QALYs, vs "no intervention". These results show that OPTI program leads to substantially higher effectiveness than only lifestyle intervention. On the 
other hand, any comparison between the two studies may not be straightforward. Galani ${ }^{70}$ compared a lifestyle intervention with standard treatment. The lifestyle intervention consisted in detailed dietary prescription and a recommendation of moderate exercise. For overweight people, standard care consisted of no intervention, whereas for obese people standard care consisted of basic dietary counselling and physical exercise sessions. Hence, the difference in effectiveness is larger in the current study than in Galani ${ }^{70}$ because the comparator is "no intervention" at all. Comparing costs between both studies did not make sense because Galvani's study is from 2007 and circumstances may have substantially changed due to variations in treatment patterns or financing systems.

Our analysis has several limitations. The first one is that the model would have benefited from the use of Swissspecific epidemiologic data on risk for complications for normal weight, overweight, and obese people instead of data from the New Zealand report. ${ }^{27}$ However, comparisons between key health indicators (Table 9) show similarities in life expectancy, average age and prevalence of diabetes, ${ }^{74}$ and consequently the use of risk of complications for Swiss model seems justified. In the same way, neither changes in utilities for weight loss were based on Swiss population, although this limitation is less important as utilities can be generalised between Western countries and do not need to be country specific. A second limitation is related to the effectiveness of OPTI program, which was taken from clinical trials assessing the OPTI program. However, in the present study, OPTI program featured only in the total and partial meal replacement component, therefore excluding physical activity and nutritional education. Finally, this study did not include smoking as a risk factor, while Galvani $^{70}$ explicitly mentions that obese smokers have a decrease in life expectancy as compared to non-smokers.

Table 9 Comparison Switzerland - New Zealand

\begin{tabular}{|l|l|l|}
\hline Determinants & Switzerland & New Zealand \\
\hline Life expectancy males & 82 years & 80 years \\
Life expectancy males & 86 years & 84 years \\
Average age: & 42.0 years & 37.0 years \\
Diabetes & $5.7 \%$ & $6.2 \%$ \\
\hline
\end{tabular}

\section{Conclusion}

The results show that OPTI program is a cost-saving weight management treatment for patients with class I and II obesity in Switzerland when compared to "no intervention" and liraglutide $3 \mathrm{mg}$. The cost savings achieved in patients with class III obesity, for whom the bariatric surgery option is added, are even more meaningful. Considering that clinical and economic advantages of OPTI program come with very few and mild adverse events, we suggest OPTI program as a preferred weight management treatment.

\section{Abbreviations}

ACS, acute coronary syndrome; BMI, body mass index; GBD, gallbladder disease; LCD, Low calorie diet; ITT, intention-to-treat; MI, myocardial infarction; QALYs, quality adjusted life years; T2DM, type 2 diabetes mellitus.

\section{Data Sharing Statement}

Data sharing is not applicable to this article as no datasets were generated or analysed during the current study.

\section{Author Contributions}

All authors made substantial contributions to conception and design, data analysis and interpretation; took part in drafting the article or revising it critically for important intellectual content; agreed to submit to the current journal; gave final approval of the version to be published; and agreed to be accountable for all aspects of the work.

\section{Funding}

Nestle Health Science. The role of the funder consisted in scientific contribution to the development of the model and review of the manuscript.

\section{Disclosure}

The brand OPTI belongs to Nestlé. LD, KAT, MP and AM are Nestlé employees.

All data analyzed in the study come from published literature and publicly disclosed clinical trial results. Nestlé founded the data elaboration and writing the manuscript. The authors report no other conflicts of interest in this work. 


\section{References}

1. Lau DC, Douketis JD, Morrison KM, Hramiak IM, Sharma AM, Ur E. 2006 Canadian clinical practice guidelines on the management and prevention of obesity in adults and children [summary]. CMAJ. 2007;176(8):S1-S13. doi:10.1503/cmaj.061409

2. National Audit Office. Tackling obesity in England: report by the comptroller and auditor general. Br J Haematol. 2013;162(1):25-39. doi:10.1111/bjh.12363

3. Guh DP, Zhang W, Bansback N, Amarsi Z, Birmingham CL, Anis AH. The incidence of co-morbidities related to obesity and overweight: a systematic review and meta-analysis. BMC Public Health. 2009;9(1):88. doi:10.1186/1471-2458-9-88

4. McKinsey Global Institute. Overcoming obesity: an initial economic analysis; 2014. Available from: https://www.google.co.uk/url?sa= $\mathrm{t} \& \mathrm{rct}=\mathrm{j} \& \mathrm{q}=\&$ esrc $=\mathrm{s} \&$ source $=$ web $\& \mathrm{~cd}=2 \& \mathrm{cad}=\mathrm{rja} \& u a c t=8 \& \mathrm{ved}=$ 0ahUKEwjErr7x4_fOAhUnIcAKHaNKBIUQFggmMAE\&url=http $\% 3 \mathrm{~A} \% 2 \mathrm{~F} \% 2 \mathrm{Fwww}$.mckinsey.com $\% 2 \mathrm{~F} \sim \% 2 \mathrm{Fmedia} \% 2 \mathrm{FMcKinsey} \%$ 2FBusiness $\% 2520 \mathrm{Functions} \% 2 \mathrm{FEconomic} \% 2520$ Studies $\%$ 2520TEMP\%2FOur\%2520Insights\%2FHow\%2520the\%2520world\% 2520 could $\% 2520$ better $\% 2520$ fight $\% 2520$ obesity\%2FMGI_ Overcoming_obesity_Ful1_report.ashx \&usg= AFQjCNF09cIsWK5RlbI19pO04CgrCkT4xA\&bvm=bv.131783435, d.d2s. Accessed September 5, 2016.

5. Ng M, Fleming T, Robinson M, et al. Global, regional, and national prevalence of overweight and obesity in children and adults during 1980-2013: a systematic analysis for the Global Burden of Disease Study 2013. Lancet. 2014;384(9945):766-781. doi:10.1016/S01406736(14)60460-8

6. World Health Organization. Updated fact sheet. Updated Fact Sheet N 311 on Obesity and Overweight; 2014 Available from http://www. wpro.who.int/mediacentre/factsheets/obesity/en/. Accessed July 24, 2017.

7. Lehnert T, Sonntag D, Konnopka A, Riedel-Heller S, Konig HH. Economic costs of overweight and obesity. Best Pract Res Clin Endocrinol Metab. 2013;27(2):105-115. doi:10.1016/j. beem.2013.01.002

8. Specchia ML, Veneziano MA, Cadeddu C, et al. Economic impact of adult obesity on health systems: a systematic review. Eur J Public Health. 2015;25(2):255-262. doi:10.1093/eurpub/cku170

9. Hruby A, Hu FB. The epidemiology of obesity: a big picture. Pharmacoeconomics. 2015;33(7):673-689. doi:10.1007/s40273-0140243-x

10. Clegg A, Colquitt J, Sidhu M, et al. Clinical and cost effectiveness of surgery for morbid obesity: a systematic review and economic evaluation. Int J Obes Relat Metab Disord. 2003;27(10):1167-1177.

11. Clegg A, Sidhu MK, Colquitt J, Royle P, Loveman E, Walker A. Clinical and cost effectiveness of surgery for morbid obesity: a systematic review and economic evaluation. Health Technol Assess. 2002;6(12):1-153.

12. Von Lengerke T, Krauth C. Economic costs of adult obesity: a review of recent European studies with a focus on subgroup-specific costs. Maturitas. 2011;69(3):220-229. doi:10.1016/j.maturitas.2011.04.005

13. Dee A, Kearns K, O'Neill C, et al. The direct and indirect costs of both overweight and obesity: a systematic review. BMC Res Notes. 2014;7(1):242. doi:10.1186/1756-0500-7-242

14. The challenge of obesity in the WHO European Region and the strategies for response/edited by Francesco Branca, Haik Nikogosian and Tim Lobstei. ISBN 978928901408 3. 2007.

15. Finkelstein EA, DiBonaventura MD, Burgess SM, Hale BC. The costs of obesity in the workplace. J Occup Environ Med. 2010;52 (10):971-976. doi:10.1097/JOM.0b013e3181f274d2

16. Picot J, Jones J, Colquitt JL, et al. The clinical effectiveness and cost-effectiveness of bariatric (weight loss) surgery for obesity: a systematic review and economic evaluation. Health Technol Assess. 2009;13(41):1-190, 215-357, iii-iv. doi:10.3310/hta13410 PMID: 19726018.
17. Hoerger TJ, Zhang P, Segel JE, Kahn HS, Barker LE, Couper S. Costeffectiveness of bariatric surgery for severely obese adults with diabetes. Diabetes Care. 2010;33(9):1933-1939. doi:10.2337/dc10-0554

18. Swiss Federal Statistical Office. Schweizeriche Gesundheitsbefragung 1992, 1997, 2002; 2006. Available from: http://www.bfs.admin.ch. Accessed August 10, 2006.

19. Schmid A, Schneider H, Golay A, Keller U. Economic burden of obesity and its co-morbidities in Switzerland. Soz.-Präventivmed. 2005;50(2):87-94. doi:10.1007/s00038-004-4067-x

20. Astbury NM, Piernas C, Hartmann-Boyce J, Lapworth S, Aveyard P, Jebb SA. A systematic review and meta-analysis of the effectiveness of meal replacements for weight loss. Obes Rev. 2019;20(4):569-587. doi:10.1111/obr.12816

21. Rothberg AE, McEwen LN, Kraftson AT, et al. Factors associated with participant retention in a clinical, intensive, behavioral weight management program. BMC Obes. 2015;2(1):11. doi:10.1186/ s40608-015-0041-9

22. Wadden TA, Foster GD, Letizia KA, Stunkard AJ. A multicenter evaluation of a proprietary weight reduction program for the treatment of marked obesity. Arch Intern Med. 1992;152(5):961-966. doi:10.1001/archinte.1992.00400170051010

23. Bischoff SC, Damms-Machado A, Betz C, et al. Multicenter evaluation of an interdisciplinary 52-week weight loss program for obesity with regard to body weight, comorbidities and quality of life-a prospective study. Int $J$ Obes. 2012;36(4):614-624. doi:10.1038/ ijo.2011.107

24. Wadden TA, Foster GD, Wang J, et al. Clinical correlates of shortand long-term weight loss. Am J Clin Nutr. 1992;56(1):271S-274S. doi:10.1093/ajen/56.1.271S

25. Drawert S, Bedford K, Largent D. Change in glucose, blood pressure, and cholesterol with weight loss in medically obese patients. Obes Res. 1996;4(S1):67S.

26. Nuijten M, Marczewska A, Araujo Torres K, Rasouli B, Perugini M. A health economic model to assess the cost-effectiveness of OPTIFAST for the treatment of obesity in the United States. J Med Econ. 2018;21 (9):835-844. [PMID: 29678127]. doi:10.1080/13696998.2018.1468334

27. Cost effectiveness report of public health interventions to prevent obesity. Report prepared for the health research council of New Zealand. HTAnalysts; October 2010. Available from: https://www. victoria.ac.nz/health/centres/health-services-research-centre/docs/ downloads/CE-Obesity-Prevention-Full-Report-publish.pdf. Accessed June 9, 2021.

28. Inflation.eu. World Inflation Data. Available from: https://www.infla tion.eu/en/inflation-rates/switzerland/historic-inflation/cpi-inflationswitzerland.aspx. Accessed June 9, 2021.

29. ISPOR. Improuing healthcare decisions. Available from: https://tools. ispor.org/peguidelines/countrydet.asp?c=25\&t=1. Accessed June 9, 2021.

30. Panje CM, Dedes KJ, Matter-Walstra K, et al.; Swiss Group for Clinical Cancer Research (SAKK). A cost-effectiveness analysis of consolidative local therapy in oligometastatic non-squamous non-small cell lung cancer (NSCLC). Radiother Oncol. 2018;129 (2):257-263. doi:10.1016/j.radonc.2018.07.017.

31. Pfeil AM, Reich O, Guerra IM, et al. Cost-effectiveness analysis of sofosbuvir compared to current standard treatment in Swiss patients with chronic hepatitis C. PLoS One. 2015;10(5):e0126984. doi:10.1371/journal.pone. 0126984 .

32. Pi-Sunyer X, Astrup A, Fujioka K, et al. Wilding JPH for the SCALE Obesity and Prediabetes NN8022-1839 Study Group: a randomized controlled trial of $3.0 \mathrm{mg}$ liraglutide in weight management. $N$ Engl J Med. 2015;373(1):11-22. doi:10.1056/NEJMoa1411892

33. Available from: https://data.worldbank.org/indicator/SP.DYN.LE00. IN?view=chart. Accessed June 9, 2021.

34. Wadden TA, Frey DL. A multicenter evaluation of a proprietary weight loss program for the treatment of marked obesity: a five-year follow-up. Int J Eat Disord. 1997;22(2):203-212. doi:10.1002/(SICI)1098-108X (199709)22:2<203::AID-EAT13>3.0.CO;2-1 
35. Toplak H, Woodward E, Yumuk V, Oppert JM, Halford JCG, Frühbeck G. 2014 EASO position statement on the use of anti-obesity drugs. Obes Facts. 2015;8(3):166-174. doi:10.1159/ 000430801

36. Pucci A, Finer N. New medications for treatment of obesity: metabolic and cardiovascular effects. Can J Cardiol. 2015;31(2):142-152. doi:10.1016/j.cjca.2014.11.010

37. Apovian CM, Aronne LJ, Bessesen DH, et al. Pharmacological management of obesity: an endocrine society clinical practice guideline. $J$ Clin Endocrinol Metab. 2015;100(2):342-362. doi:10.1210/jc.2014-3415

38. Wadden TA, Hollander P, Klein S, et al. NN8022-1923 Investigators: weight maintenance and additional weight loss with liraglutide after low-calorie-diet-induced weight loss: the SCALE maintenance randomized study. Int $J$ Obes. 2013;37(11):1443-1451. doi:10.1038/ ijo. 2013.120

39. Andersen T, Stokholm KH, Backer OG, Quaade F. Long-term (5-year) results after either horizontal gastroplasty or very low-calorie diet for morbid obesity. Int J Obes Relat Metab Disord. 1988;12:277-284.

40. Andersen T, Backer OG, Stokholm KH, Quaade F. Randomized trial of diet and gastroplasty compared with diet alone in morbid obesity. $N$ Engl $J$ Med. 1984;310(6):352-356. doi:10.1056/ NEJM198402093100604

41. Quaade F. Studies of operated and nonoperated obese patients. An interim report on the Scandinavian obesity project. Am J Clin Nutr. 1977;30(1):16-20. doi:10.1093/ajcn/30.1.16

42. Backer O, Gudmand-Hoyer E, Andersen B, Baden H, Martiny P, Juhl E. Randomised trial of jejunoileal bypass versus medical treatment in morbid obesity. The Danish Obesity Project. Lancet. 1979;2:1255-1258.

43. Karason K, Wallentin I, Larsson B, Sjostrom L. Effects of obesity and weight loss on left ventricular mass and relative wall thickness: survey and intervention study. Br Med J. 1997;315(7113):912-916. doi:10.1136/bmj.315.7113.912

44. Sjostrom CD, Peltonen M, Sjostrom L. Blood pressure and pulse pressure during long-term weight loss in the obese: the Swedish obese subjects (sos) intervention study. Obes Res. 2001;9 (3):188-195. doi:10.1038/oby.2001.20

45. Torgerson JS, Sjostrom L. The Swedish Obese Subjects (SOS) study - rationale and results. Int $J$ Obes. 2001;25(supp1):s2-s4. doi:10.1038/sj.ijo.0801687

46. Jung RT, Cuschieri A. Obese patients. In: Cuschieri A, Steele RJC, Moosa AR, editors. Essential Surgical Practice-Volume 1. 4th ed. Butterworth Heinemann; 2000:227-240.

47. Nafees B, Stafford M, Gavriel S, Bhalla S, Watkins J. Health state utilities for non small cell lung cancer. Health Qual Life Outcomes. 2008;6(1):84. doi:10.1186/1477-7525-6-84

48. Restelli U, Saibene G, Nardulli P, et al. Cost-utility and budget impact analyses of the use of NEPA for chemotherapy-induced nausea and vomiting prophylaxis in Italy. BMJ Open. 2017;7(7): e015645. doi:10.1136/bmjopen-2016-015645

49. Lane S, Levy AR, Mukherjee J, Sambrook J, Tildesley H. The impact on utilities of differences in body weight among Canadian patients with type 2 diabetes. Curr Med Res Opin. 2014;30(7):1267-1273. doi:10.1185/03007995.2014.899207.

50. Hakim Z, Wolf A, Garrison LP. Estimating the effect of changes in body mass index on health state preferences. Estimating the effect of changes in body mass index on health state preferences. Pharmacoeconomics. 2002;20(6):393-404. doi:10.2165/00019053200220060-00004

51. Grima DT, Brown ST, Kamboj L, et al. Cost-effectiveness of ticagrelor versus clopidogrel in patients with acute coronary syndromes in Canada. Clinicoecon Outcomes Res. 2014;6:49-62. doi:10.2147/ CEOR.S51052
52. McQueen RB, Breton MD, Ott M, Koa H, Beamer B, Campbell JD Economic Value of Improved Accuracy for Self-Monitoring of blood glucose devices for type 1 diabetes in Canada. J Diabetes Sci Technol. 2016;10(2):366-377. doi:10.1177/1932296815599551

53. Marra C, Johnston K, Santschi V, Tsuyuki RT. Cost-effectiveness of pharmacist care for managing hypertension in Canada. Can Pharm J. 2017;150(3):184-197. doi:10.1177/1715163517701109

54. Lachaine J, Beauchemin C, Mathurin K, Gilbert D, Beillat M. Costeffectiveness of asenapine in the treatment of bipolar disorder in Canada. BMC Psychiatry. 2014;14(1):16. doi:10.1186/1471-244X14-16

55. Marsh JD, Birmingham TB, Giffin JR, et al. Cost-effectiveness analysis of arthroscopic surgery compared with non-operative management for osteoarthritis of the knee. BMJ Open. 2016;6(1): e009949. doi:10.1136/bmjopen-2015-009949

56. Blank PR, Moch H, Szucs TD, Schwenkglenks M. KRAS and BRAF mutation analysis in metastatic colorectal cancer: a cost-effectiveness analysis from a Swiss perspective. Clin Cancer Res. 2011;17 (19):6338-6346. doi:10.1158/1078-0432.CCR-10-2267

57. Blank PR, Filipits M, Dubsky P, et al. Cost-effectiveness analysis of prognostic gene expression signature-based stratification of early breast cancer patients. Pharmacoeconomics. 2015;33(2):179-190. doi:10.1007/s40273-014-0227-x

58. Koerber F, Waidelich R, Stollenwerk B, et al. The cost-utility of open prostatectomy compared with active surveillance in early localised prostate cancer. BMC Health Serv Res. 2014;14(163). doi:10.1186/ 1472-6963-14-163

59. Hoyle M, Green C, Thompson-Coon J, et al. Cost-effectiveness of sorafenib for second-line treatment of advanced renal cell carcinoma. Value Health. 2009;13(1):55-60. doi:10.1111/j.1524-4733.2009.00616.x

60. Kwon JS, Carey MS, Goldie SJ, Kim JJ. Cost-effectiveness analysis of treatment strategies for Stage I and II endometrial cancer. $J$ Obstet Gynaecol Can. 2007;29(2):131-139. doi:10.1016/S1701-2163(16) 32387-8

61. Adam V, Bhat M, Martel M, et al. Comparison costs of ERCP and MRCP in patients with suspected biliary $\mathrm{O}$ bstruction Based on a Randomized Trial. Value Health. 2015;18(6):767-773. doi:10.1016/j.jval.2015.04.009

62. McKeever T, Mortimer L, Bradshaw L, et al. Temporarily quadrupling the dose of inhaled steroid to prevent asthma exacerbation. Health Technol Assess. 2018;22(70):1-82. doi:10.3310/hta22700

63. Coyle D, Coyle K, Cameron C, et al. Cost-effectiveness of new oral anticoagulants compared with warfarin in preventing stroke and other cardiovascular events in patients with atrial fibrillation. Value Health. 2013;16(4):498-506. doi:10.1016/j.jval.2013.01.009

64. Gurusamy KS, Riviere D, van Laarhoven CJH, et al. Costeffectiveness of laparoscopic versus open distal pancreatectomy for pancreatic cancer. PLoS One. 2017;12(12):e0189631. doi:10.1371/ journal.pone.0189631

65. Filby A, Taylor M, Lipman G, Lovat L, Haidry R. Cost-effectiveness analysis of endoscopic eradication therapy for treatment of highgrade dysplasia in Barrett's esophagus. J Comp Eff Res. 2017;6 (5):425-436. doi:10.2217/cer-2016-0089

66. compendium.ch. Available from: https://compendium.ch/search?q= saxenda. Accessed June 9, 2021.

67. Schneider H, Venetz W, Ag D. Cost of Obesity in Switzerland in 2012.

68. Pollock RF, Valentine WJ, Goodall G, Brändle M. Evaluating the cost-effectiveness of self-monitoring of blood glucose in type 2 diabetes patients on oral anti-diabetic agents. Swiss Med Wkly. 2010;140:w13103. doi:10.4414/smw.2010.13103

69. Weber C, Schneider B, Lodwig V, Holm MV, Neeser K. Cost impact of blood glucose self-monitoring on complications of type 2 diabetes: a Swiss perspective (ROSSO study No.11). Swiss Med Wkly. 2007;137(39-40):545-550 
70. Galani C, Schneider H, Rutten FF. Modelling the lifetime costs and health effects of lifestyle intervention in the prevention and treatment of obesity in Switzerland. Int J Public Health. 2007;52(6):372-382. doi:10.1007/s00038-007-7014-9

71. Huber CA, Diem P, Schwenkglenks M, Rapold R, Reich O. Estimating the prevalence of comorbid conditions and their effect on health care costs in patients with diabetes mellitus in Switzerland. Diabetes Metab Syndr Obes. 2014;7:455-465. doi:10.2147/DMSO.S69520

72. Brändle M, Goodall G, Erny-Albrecht KM, Erdmann E, Valentine WJ. Cost-effectiveness of pioglitazone in patients with type 2 diabetes and a history of macrovascular disease in a Swiss setting. Swiss Med Wkly. 2009;139(11-12):173-184
73. xe.Available from: https://www.xe.com/currencytables/?from= EUR\&date=2019-07-01. Accessed June 9, 2021.

74. WorldData.info.Available from: https:/www.worlddata.info/countrycomparison.php? country $1=\mathrm{CHE} \&$ country $2=\mathrm{NZL}$. Accessed June 9, 2021.

\section{Publish your work in this journal}

Diabetes, Metabolic Syndrome and Obesity: Targets and Therapy is an international, peer-reviewed open-access journal committed to the rapid publication of the latest laboratory and clinical findings in the fields of diabetes, metabolic syndrome and obesity research. Original research, review, case reports, hypothesis formation, expert opinion and commentaries are all considered for publication. The manuscript management system is completely online and includes a very quick and fair peer-review system, which is all easy to use. Visit http://www.dovepress.com/testimonials.php to read real quotes from published authors. 